The library is in receipt of 558 different serial publications, an increase of 12 over the preceding year. As heretofore, nearly all of these are obtained through exchange for the Journal of the Franklin Institute, and they comprise issues in various languages from all quarters of the globe.

The library has been kept open until to o'clock on Thursday evenings, when the Section meetings occur, and on the occasion of the monthly meeting of the Institute on the third Wednesday evening. The number of visitor's after night-fall tends rather to diminish than otherwise, and appears to be limited almost entirely to members attending the meetings. The daily attendance, on the other hand, is on the increase, indicating the growing importance of the library as a factor in the city's intellectual life.

Phit_aDA., January I, 1906.

Louis E. Levy,

Chairman.

\title{
REPORT OF THE COMMITTEE ON SCIENCE AND THE ARTS
} FOR THE YEAR I9O5.

\section{To the President and Members of the Franklin Institute:}

The Committee on Science and the Arts has the honor to submit the following account of its operations during the year I905:

The total number of cases pending at the close of the year 1904 was 43 , and the new cases proposed in 1905 numbered 26.

The total number of cases disposed of during 1905 was 28 , leaving $4 \mathrm{I}$ cases pending at the present time.

There were granted, I "Elliott-Cresson Medal;" I4 "John Scott Medals;" 6 "Edward Longstreth Medals;" (21 medals in all). Two "Certificates of Merit" were awarded, and in five cases advisory reports were made.

The detailed statistics of the Committee will be found hereto appended.

The Chairman of the Committee has much pleasure in reporting that the efficiency of the Committee has been well maintained.

Respectfully sumbitted,

Philadelphia, PA, January 3, Igo6.

E. Goldsmith,

Chairman for 1905.

\section{Appendix.}

DETAILS OF THE COMMITTEE'S WORK IN 1905.

Number of cases pending on December 3r, 1904..........43

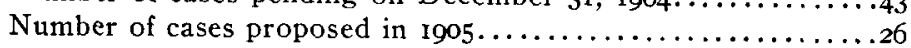

Total number of cases before the Committee in $1905 . . . . .$.

Total number of cases finally disposed of in $1905 \ldots \ldots \ldots \ldots 28$

Total number of cases pending on December $3 \mathrm{I}$, I905 . . . .

The 28 cases disposed of were determined as follows:

Award of the Elliott Cresson Medal.................. I

Award of the John Scott Legacy Premium and Medal........... 